\title{
Sciendo
}

\section{Insulin resistance and testosterone level in Indonesian young adult males}

\author{
LIONG BOY KURNIAWAN ${ }^{1}$, ENDY ADNAN ${ }^{2}$, WINDARWATI ${ }^{3}$, BUDI MULYONO ${ }^{3}$ \\ ${ }^{1}$ Clinical Pathology Department, Faculty of Medicine, Hasanuddin University, Makassar, Indonesia \\ ${ }^{2}$ Internal Medicine Department, Faculty of Medicine, Hasanuddin University, Makassar, Indonesia \\ ${ }^{3}$ Clinical Pathology Department, Faculty of Medicine, Gadjah Mada University, Yogyakarta, Indonesia
}

\begin{abstract}
Introduction. Central obesity is characterized by the accumulation of abdominal fat which may lead to several diseases including insulin resistance. The prevalence of central obesity is higher in male and the incidence in young adult males is increased. Central obesity is also related to low testosterone levels. The research aimed to assess the relationship between the testosterone levels and insulin resistance of young adult males with central obesity.

Methods. This was a cross-sectional study, the subjects were young adult males of 18 to 25 years old. The central obesity consisted of 50 samples and non-central obesity comprised 70 samples. The examination of testosterone and insulin was performed by the ECLIA method, glucose used the enzymatic method, the insulin resistance was calculated by using the HOMA-IR index.

Results. The mean of the testosterone level in central obesity was lower than non-central obesity $(5.24 \pm 1.17$ vs $7.18 \pm 1.54 \mathrm{ng} / \mathrm{mL}, \mathrm{p}<0.001)$. HOMA-IR index in central obesity was higher than non-central obesity $(4.29 \pm 2.23$ vs $2.46 \pm 1.72, \mathrm{p}<0.001)$. Testosterone levels had negative correlation with HOMA-IR $(\mathrm{r}=-0.470, \mathrm{p}<0.001)$. There was significant difference in HOMA-IR among the quartiles of testosterone levels.

Conclusion. There is negative correlation between testosterone level with HOMA-IR, the lower the testosterone level the higher the insulin resistance in young adult males.
\end{abstract}

Key words: young adult, male, testosterone, HOMA-IR, insulin resistance.

\section{INTRODUCTION}

Obesity is a condition characterized by excessive or abnormal fat accumulation that can interfere with health [1]. The number of overweight people is estimated at around 1.2 billion worldwide with around 300 million people are obese [2]. The prevalence of overweight and obesity in Indonesia is increasing from year to year, especially in the last two decades. It is higher in boys than girls, but in the adolescent and adult populations, it is found to be higher in females. The prevalence is also higher in urban areas and populations with higher incomes and education [3].

A common parameter that is often used to assess obesity in addition to body mass index is the waist circumference. Measurement of waist circumference is simpler and easier to perform, used to assess the quantity of fat in the abdomen. Waist circumference is independently correlated with risk factors for cardiovascular disease [1]. The International Diabetes Federation (IDF) recommends waist circumference $\geq 90 \mathrm{~cm}$ in men and $\geq 80 \mathrm{~cm}$ in women as central obesity [4].

Obesity is associated with chronic micro inflammatory conditions. In obese people, proinflammatory cytokine, tumor necrosis factor (TNF) $-\alpha$ is expressed by fat tissue and is associated with insulin resistance. Dysfunctional lipid metabolism in obesity can interfere with insulin signaling. Free fatty acids (FFA) which circulate may suppress the action of insulin in target organs [5-7].

Obesity in males is often associated with a decrease in testosterone levels both in free and total form. Testosterone levels decrease along with the increase of body mass index [8]. Endogenous androgens such as testosterone have protective effect on obesity and metabolic syndrome. In men with low testosterone levels, the incidence of metabolic syndrome is higher [9]. Low testosterone levels in obese men with type 2 diabetes mellitus (DM II) also contribute to sexual dysfunction and the risk of cardiovascular disease [10].

Androgens in humans consist of testosterone, dihydrotestosterone (DHT), androstenedione and Dehydroepiandrosterone (DHEA) and DHEA that bind to sulfates (DHEAS). Testosterone is secreted by male testes and in smaller amounts by female ovaries. It is estimated that as much as $5 \%$ of testosterone in the serum is converted to DHT by a $5 \alpha$ reduction process. The majority of testosterone $(50-60 \%)$ is bound to a plasma protein called sex-hormone-binding globulin (SHBG), 40-50\% bound to albumin and $1-2 \%$ in the free form [9]. 
Some males with women relatives/siblings suffering from polycystic ovarian syndrome (PCOS) are reported to have the same hormonal, clinical, and metabolic alterations as PCOS patients which marked with higher prevalence of hyperinsulinemia, hypertriglyceridemia, hypertension, and dyslipidemia leading to cardiovascular disease and DM II. It suggests that they may inherit the genes responsible for PCOS susceptibility [11].

Although several studies have found a negative correlation between central obesity in men and testosterone levels, research regarding the relationship between central obesity, insulin resistance and testosterone which focuses on young adult males in Indonesia is still rarely conducted. The research aimed to assess the relationship between testosterone levels and insulin resistance in young adult males.

\section{MATERIAL AND METHODS}

\section{Study population}

This research was an analytic study with cross-sectional design. This study was conducted from August 2017 to June 2018. The research subjects were the students of the Medical Faculty, Hasanuddin University, Indonesia, in the first to the sixth year grade. Inclusion criteria were male aged 18-25 years who were willing to participate in the study by filling out and signing informed consent. Exclusion criteria were subjects suffering from diabetes mellitus, taking corticosteroid drugs or cholesterol-lowering drugs. The research subjects were then divided into 2 groups, central obesity, and non-central obesity. A total of 120 people were recruited in the study, with 70 subjects classified as non central obesity while 50 subjects were classified as central obesity, using IDF criteria.

In conducting this research, we had the permission of the subjects/volunteers through informed consent sheets and declared that this research met the ethical requirements approved by the Health Research Ethics Commission (KEPK) Faculty of Medicine, Hasanuddin University - RSPTN UH RSUP Dr. Wahidin Sudirohusodo, Makassar Number: 1070/H4.8.4.5.31/PP36-KOMETIK / 2017.

\section{Laboratory procedure}

Anthropometric (waist circumference) measurement, blood sampling, and glucose test were performed at the Clinical Pathology Laboratory, Hasanuddin University Hospital, while serum storage, testosterone and insulin tests were conducted at the Research Unit of the Hasanuddin University Hospital, Makassar, Indonesia.

Research subjects who met the inclusion criteria were asked to fast for 8-12 hours overnight. On the same day as blood sampling, the waist circumference of the subjects was measured. A total of $3 \mathrm{cc}$ venous blood of each subject was taken using a vacutainer. The serum was separated and directly used for blood glucose testing. The remaining serum then was stored at $-40^{\circ} \mathrm{C}$ until the time of testosterone and insulin tests. Glucose test was performed using ABX Pentra 400 (Horiba, Japan), while testosterone, and insulin were tested by Cobas ${ }^{\circledR}$ e411 tool (Roche, Germany) using electrochemiluminescence (ECLIA) method. The homeostatic model assessment of insulin resistance (HOMA-IR) index was used to measure the insulin resistance, calculated by using the formula: HOMA-IR = [fasting plasma glucose $(\mathrm{mg} / \mathrm{dL}) \times$ insulin $(\mu \mathrm{IU} / \mathrm{mL}) / 405]$.

\section{Statistical analysis}

The normality distribution of the parameters was tested by the Kolmogorov-Smirnov test. The comparative test of numerical variables on normally distributed data was analyzed by the T-test while on the data that was not normally distributed analyzed with the Mann Whitney test. The correlation test on normally distributed data was tested with the Pearson correlation test while on the data that was not normally distributed tested with the Spearman correlation test. The comparative test of normally distributed numerical variables of more than two groups was tested with the One Way Anova Test while those that were not normally distributed tested with Kruskal Wallis test. The statistical analyses were performed by using the Statistical Package for the Social Sciences (SPSS), Version 21.0.

\section{RESULTS}

Among 120 study subjects, 70 (58.3\%) subjects were classified as non-central obesity while 50 (41.7\%) subjects were classified as central obesity. The age range of the study subjects was $18-25$ years with waist circumference ranged from $66-136 \mathrm{~cm}$. Normality test with Kolmogorov Smirnov showed fasting blood glucose levels were normally distributed while age, waist circumference, insulin, HOMA-IR, and testosterone were not normally distributed. The general characteristics of the study subjects were shown in Table 1. 
Table 1

Characteristics of research subjects

\begin{tabular}{|l|c|c|c|c|}
\hline \multicolumn{1}{|c|}{ Parameters } & Mean \pm SD & Median & Minimum & Maximum \\
\hline Age $($ years $)$ & $21.01 \pm 1.71$ & 21 & 18 & 25 \\
\hline WC $(\mathrm{cm})$ & $88.79+14.94$ & 87 & 66 & 136 \\
\hline FPG $(\mathrm{mg} / \mathrm{dL})$ & $96.87 \pm 8.50$ & 96 & 78.1 & 124.9 \\
\hline Insulin $(\mu \mathrm{IU} / \mathrm{mL})$ & $13.31 \pm 8.28$ & 11.4 & 3.52 & 46.82 \\
\hline HOMA-IR & $3.22+2.15$ & 2.69 & 0.68 & 14.22 \\
\hline Testosterone $(\mathrm{ng} / \mathrm{mL})$ & $6.37+1.69$ & 6.18 & 3.17 & 12.95 \\
\hline
\end{tabular}

$\mathrm{SD}=$ Standard Deviation, $\mathrm{WC}=$ Waist Circumference, $\mathrm{FPG}=$ Fasting Plasma Glucose, HOMA-IR = Homeostasis Model Assessment of Insulin Resistance Index.

Differences in fasting glucose, insulin, testosterone and HOMA-IR index in central obesity and non-central obesity were shown in Table 2. Insulin and HOMA-IR were higher in the central obesity group while testosterone was lower in the central obesity group.

Table 3 showed that testosterone levels in young adult males had negative correlation with waist circumference, insulin, and HOMA-IR.
Testosterone levels were divided into 4 quartiles and the difference in HOMA-IR values in the 4 quartiles was analyzed in Table 4.

This study used a HOMA-IR cut-off above the 75th percentile to define insulin resistance. The cutoff value used to determine insulin resistance was $>3.8$. Testosterone levels were divided into 4 quartiles to analyze the Odds Ratio (OR) of having insulin resistance from interquartile compared to quartile 1 which was shown in Table 5.

Table 2

Differences of waist circumference, insulin resistance and testosterone levels in the non-central obesity and central obesity groups

\begin{tabular}{|l|c|c|c|}
\hline \multicolumn{1}{|c|}{ Parameters } & $\begin{array}{c}\text { Non-Central Obese } \\
\mathbf{n = 7 0}\end{array}$ & $\begin{array}{c}\text { Central Obese } \\
\mathbf{n}=\mathbf{5 0}\end{array}$ & p value \\
\hline Age $($ years) & $21.01 \pm 2.02$ & $21 \pm 1.18$ & $0.884^{\#}$ \\
\hline WC $(\mathrm{cm})$ & $78.39 \pm 6.61$ & $103.35 \pm 10.48$ & $<0.001^{\#}$ \\
\hline FPG $(\mathrm{mg} / \mathrm{dL})$ & $96.47 \pm 8.80$ & $97.42 \pm 8.12$ & $0.552^{*}$ \\
\hline Insulin $(\mu \mathrm{IU} / \mathrm{mL})$ & $10.08 \pm 5.89$ & $17.83 \pm 9.05$ & $<0.001^{\#}$ \\
\hline HOMA-IR & $2.46 \pm 1.72$ & $4.29 \pm 2.23$ & $<0.001^{\#}$ \\
\hline Testosterone $(\mathrm{ng} / \mathrm{mL})$ & $7.18 \pm 1.54$ & $5.24 \pm 1.17$ & $<0.001^{\#}$ \\
\hline
\end{tabular}

T Test, ${ }^{\#}$ Mann Whitney Test, SD $=$ Standard Deviation, WC $=$ Waist Circumference, FPG $=$ Fasting Plasma Glucose, HOMA-IR $=$ Homeostasis Model Assessment of Insulin Resistance Index.

Table 3

Correlation of testosterone with waist circumference and insulin resistance

\begin{tabular}{|l|c|c|}
\hline \multicolumn{1}{|c|}{ Parameters } & \multicolumn{2}{|c|}{ Testosterone } \\
\hline & r & \multicolumn{1}{|c|}{ p } \\
\hline WC $(\mathrm{cm})$ & -0.563 & $<0.001^{\#}$ \\
\hline FPG $(\mathrm{mg} / \mathrm{dL})$ & -0.103 & $0.264^{\#}$ \\
\hline Insulin $(\mu \mathrm{IU} / \mathrm{mL})$ & -0.485 & $<0.001^{\#}$ \\
\hline HOMA-IR & -0.470 & $<0.001^{\#}$ \\
\hline
\end{tabular}

\# Spearman Correlation Test, WC $=$ Waist Circumference, FPG = Fasting Plasma Glucose, HOMA-IR = Homeostasis Model Assessment of Insulin Resistance Index.

Table 4

Differences in HOMA-IR values between quartiles of testosterone levels

\begin{tabular}{|c|c|c|c|c|}
\hline \multirow{2}{*}{ Testosterone Quartiles } & \multirow{2}{*}{} & \multicolumn{2}{|c|}{ HOMA-IR } & p value \\
\cline { 3 - 5 } & & Mean \pm SD & Median (Min-Max) & $<0.001$ \\
\hline $4(7.22-12.95)$ & 30 & $2.19 \pm 0.94$ & $2.12(0.68-3.90)$ & \\
\hline $3(6.18-7.21)$ & 29 & $2.73 \pm 1.49$ & $2.45(1.18-8.31)$ & \\
\hline $2(5.29-6.17)$ & 31 & $3.42 \pm 2.87$ & $2.33(1.21-14.22)$ & \\
\hline $1(3.17-5.28)$ & 30 & $4.53 \pm 2.06$ & $4.11(1.72-10.03)$ & \\
\hline
\end{tabular}

*Kruskal Wallis Test. 
Table 5

The odds ratio of having insulin resistance based on quartile testosterone levels

\begin{tabular}{|l|l|c|c|c|c|c|l|}
\hline & & \multicolumn{3}{|c|}{ Insulin Resistance } & & \multicolumn{1}{c|}{ OR (CI 95\%) } \\
\hline & & \multicolumn{2}{|c|}{ Resistance } & \multicolumn{2}{c|}{ Sensitive } & p value & \\
\hline & & $\mathbf{n}$ & $\mathbf{\%}$ & $\mathbf{n}$ & $\mathbf{\%}$ & & \\
\hline Testosterone Quartile & $4(7.22-12.95)$ & 1 & 3.3 & 29 & 96.7 & $<0.001$ & $0.03(0.004-0.251)$ \\
\hline & $3(6.18-7.21)$ & 5 & 17.2 & 24 & 82.8 & $<0.001$ & $0.182(0.055-0.606)$ \\
\hline & $2(5.29-6.17)$ & 8 & 25.8 & 23 & 74.2 & $<0.001$ & $0.3(0.1-0.894)$ \\
\hline Total & $1(3.17-5.28)$ & 16 & 53.3 & 14 & 46.7 & & Reference \\
\hline
\end{tabular}

\section{DISCUSSION}

In this study, no significant differences in fasting blood glucose levels were found between the central obesity and non-central obesity groups. Waist circumference was significantly greater in the central obesity group than in non-central obesity. Insulin and HOMA-IR were significantly higher in the central obesity group but testosterone levels were lower in the central obesity group than in non-central obesity. Although fasting glucose levels in central obesity and non-central obesity groups were not significantly different, fasting insulin levels in the central obesity group were significantly higher. This indicates that in young adult males with central obesity, although fasting glucose levels can still be controlled, it needs higher insulin levels to is control the glucose levels compared to the non-central obesity group.

In this study, it was found that testosterone levels in young adult subjects with central obesity were significantly lower than non-central obesity $(5.24+1.17$ vs $7.18+1.54 \mathrm{ng} / \mathrm{mL})$. This is in line with the results of previous studies which reported that testosterone levels were found to be lower in obese men compared to non-obese ones $(p<0.001)$ [12].

Several theoretical mechanisms are underlying the decline in testosterone levels in men with central obesity. The aromatization of testosterone to estradiol, impaired secretion of the pituitary hormone FSH and LH, decreased synthesis of testosterone by testicular Leydig cells and decreased SHBG production are proposed to describe the mechanism [13]. The aromatization process will form estradiol in adipose tissue. The estradiol then binds to the receptors in the hypothalamus and may reduce the frequency of GnRH pulsation and cause reduced LH secretion in the pituitary, thereby reducing the synthesis of testosterone in testicular Leydig cells. In obesity, increased leptin causes chronic leptin resistance which can suppress the normal secretion of hypothalamic GnRH. Increased circulating leptin levels can also inhibit the stimulating effect of LH on Leydig cells and inhibit the conversion of 17-hydroxyprogesterone steroid precursors into testosterone in cells. Adipose tissue also secretes pro-inflammatory cytokines such as TNF- $\alpha$ and IL-6 which can decrease testosterone synthesis by directly affecting Leydig cell steroidogenesis. Proinflammatory cytokines can also disrupt insulin signals and cause hyperinsulinemia which can suppress the secretion of hypothalamic GnRH and pituitary LH $[13,14]$. In obesity, there is a decrease in SHBG production due to reduced hepatic globulin synthesis because of excess insulin in the circulation of men with high BMI [8].

In this study, testosterone levels were found to be negatively correlated with waist circumference $(\mathrm{r}=-0.563, \mathrm{p}<0.001)$. The relationship between testosterone and obesity seems to be a two-way relationship. Obesity can be induced by androgen deficiency and conversely, hypogonadism can be induced by obesity. This is called the HypogonadismObesity Cycle Hypothesis [15]. Severe obesity has a negative impact on the hypothalamic-pituitarygonad in the male. Low testosterone levels are also a predisposing factor to central adiposity. Testosterone affects visceral fat metabolism by stimulating lipolysis. In vitro tests show testosterone stimulates lipolysis induced by catecholamines by increasing the number of adrenergic receptors on mouse adipocyte precursor cells. Castration in male rats reduces lipolysis, by contrast, testosterone therapy induces lipolysis. In men with central obesity, testosterone also reportedly inhibits lipoprotein lipase activity in abdominal adipose tissue thereby reducing the uptake of triglycerides in visceral fat. Low testosterone levels predispose to central obesity, cause fatty acid dysregulation and trigger insulin resistance [16].

Testosterone was also found to be negatively correlated with HOMA-IR $(\mathrm{r}=-0.470, \mathrm{p}<0.001)$. Testosterone levels were negatively correlated with insulin resistance. The cross-sectional research model cannot explain the causal relationship between 
testosterone and insulin resistance. In male rats, it is reported that castration triggers the development of insulin resistance rapidly. In men with prostate cancer, induction of hypogonadism with gonadotropinreleasing hormone agonists causes a $60 \%$ increase in fasting insulin levels within 3 months. Giving androgens in centrally obese men with low to normal testosterone levels increases insulin sensitivity. One study showed that the correlation between testosterone and insulin sensitivity becomes insignificant after body mass index was controlled, showing that obesity was a cause of low testosterone levels and insulin resistance, with no direct relationship was found between testosterone and insulin sensitivity. The second possible explanation was the effect of testosterone on insulin sensitivity was mediated through the changes in body mass index [16]. Glucose transporter type 4 (GLUT4) and Insulin receptor substrate 1 (IRS1) in adipocyte and skeletal muscle cells were upregulated after being given a small dose of testosterone and incubated for a short time [17]. Waist circumference was reported to predict the occurrence of insulin resistance and hypogonadism in men [18].

Significant differences in HOMA-IR values were found in the four quartiles of testosterone levels. The higher the quartile of testosterone levels the lower the HOMA-IR value (the better the insulin sensitivity). Similar results were found in studies in male populations in China [19]. Research in the male population with metabolic syndrome also found the same thing, the lower the quartile of testosterone levels, the higher the HOMA-IR (the higher the insulin resistance) [20].

Odds ratio suffering from insulin resistance in young adult men with testosterone levels in quartile 4 is 0.03 compared to quartile 1 , in quartile 3 is 0.182 compared to quartile 1 and in quartile 2 is 0.3 times compared to quartile 1 . The higher the quartile of Testosterone levels the lower the risk of the occurrence of insulin resistance in young adult males.

Testosterone is thought to improve glucose metabolism by modulating the expression of glucose transporter 4, insulin receptors and regulating glycolysis-related enzymes [19] so that increasing testosterone levels will improve glucose metabolism which ultimately improves insulin sensitivity. Research on murine also reported that testosterone could protect pancreatic $\beta$ cells from glucotoxicityinduced apoptosis [21].

In conclusion, we demonstrated that in young adult males, the higher the waist circumference the lower the testosterone level, and the lower the testosterone level the higher the insulin resistance (HOMA-IR).

This study has limitations. The cross-sectional design can not explain the causality between obesity, testosterone levels, and HOMA-IR even though the relationship between these variables is statistically significant.

Introducere. Obezitatea centrală este caracterizată prin acumularea de grăsime ce duce la rezistență la insulină. Prevalența obezității de tip central este mai mare la bărbaţi, iar incidența la adulții tineri este în creștere. Obezitatea centrală este asociată și cu niveluri scăzute de testosteron. Scopul cercetării a fost de a evalua legătura dintre nivelurile de testosteron și insulină și obezitatea centrală la adulții tineri de gen masculin.

Materiale şi metode. S-a realizat un studiu transversal in care au fost recrutați bărbați cu vârstele între 18 și 25 ani. 50 de pacienți au avut obezitate centrală și 70 de pacienți nu au avut obezitate centrală. Nivelurile de insulină și testosteron au fost evaluate prin ECLIA, iar rezisența la insulină a fost evaluată prin HOMA-IR.

Rezultate. Media testosteronului la pacienții cu obezitate centrală era semnificativ mai mică $(5.24 \pm 1.17$ vs $7.18 \pm 1.54 \mathrm{ng} / \mathrm{mL}, p<0.001)$. Indexul HOMA-IR la pacienții cu obezitate centrală a fost semnificativ mai mare la pacienții cu obezitate centrală. Nivelurile de testosteron s-au corelat negativ cu HOMA-IR ( $r=-0.470, p<0.001)$. A fost o diferență semnificativă intre valorile HOMA-IR la cvartilele nivelurilor de testosteron.

Concluzii. La adulții tineri cu obezitate centrală s-a observat o asociere negativă între nivelurile testosteronului și HOMA-IR: cu cât nivelurile de testosteron sunt mai mici, cu atât rezistența la insulină este mai mare. 
Correspondence to: Liong Boy Kurniawan, Medical Faculty, Hasanuddin University, Perintis Kemerdekaan KM 10 Road, Makassar, Indonesia

Tel.: + 6281241738007

E-mail: liongboykurniawan@yahoo.com

Conflict of interest disclosure: The authors state that they have no conflicts of interest regarding this article publication.

\section{REFERENCES}

1. ELLULU M., ABED Y., RAHMAT A., RANNEH Y., ALI F., Epidemiology of obesity in developing countries: challenges and prevention, Global Epidemic Obesity, 2014.

2. WILBORN C., BECKHAM J., CAMPBELL B., HARVEY T., GALBREATH M., BOUNTY P.L. et al., Obesity: prevalence, theories, medical consequences, management, and research directions, J. Int. Soc. Sport. Nutr., 2005, 2(2):4-31.

3. RACHMI C.N., LI M., BAUR L.A., Overweight and obesity in Indonesia: prevalence and risk factors - a literature review, Public Health, 2017, 147:20-29.

4. ALBERTI K.G., ZIMMET P., SHAW J., Metabolic syndrome - a new world wide definition. A concencus state from the International Diabetes Federation, Diabet. Med., 2006, 23:469-480.

5. KARPE F., DICKMANN J.R., FRAYN K.N., Fatty acids, obesity, and insulin resistance: time for reevaluation, Diabetes, 2011; 60:2441-2447.

6. MCARDLE M.A., FINUCANE O.M., CONNAUGHTON R.M., MCMORROW A.M., ROCHE H.M., Mechanisms of obesityinduced inflamation and insulin resistance: insights into emerging role of nutritional strategies, Front. Endocrinol., $2013,4: 52$.

7. TCHERNOF A., DESPRES J.P., Pathophysiology of Human Visceral Obesity: An Update, Physiol. Rev., 2013, 93:359-404.

8. PASQUALI R., VICENNATI V., GAMBINERI A., PAGOTTO U., Sex-Dependent Role of Glucocorticoids and Androgens in the Pathophysiology of Human Obesity, Int. J. Obes., 2008, 32(12):1764-1779.

9. BIANCHI V.E., Metabolic Syndrome, Obesity Paradox and Testosterone Level, Endocrinol. Metab. Synd., 2015, 4(2):1-16.

10. WANG C., JACKSON G., JONES T.H., MATSUMOTO A.M., NEHRA A., PERELMAN M.A. et al., Low Testosteron Associated with Obesity and the Metabolic Syndrome Contributes to Sexual Dysfunction and Cardiovascular Disease Risk in Men with Type 2 Diabetes, Diabetes Care, 2011, 34:1669-1673.

11. DI GUARDO F., CERANA M.C., D’URSO G., GENOVESE F., PALUMBO M., Male PCOS equivalent and nutritional restriction: are we stepping forward?, Med. Hypotheses, 2019, 126:1-3.

12. WU F., TAJAR A., PYE S.R., SILMAN A.J., FINN J.D. et al., Hypothalamic - Pituitary - Testicular Axis Disruptions in Older Men are Differentially Linked to Age and Modifiable Risk Factors: The European Male Aging Study, J. Clin. Endocrinol. Metab., 2008, 93:2737-2745.

13. TREMELLEN K., PEARCE K., Nutrition, Fertility, and Human Reproductive Function, CRC Press, Florida, 2015:58-261.

14. HOHL A., Testosterone from Basic to Clinical Aspects, Springer, Switzerland, 2017:149-159.

15. KELLY D.M., JONES T.H., Testosterone: A Metabolic Hormone in Health and Disease, J. Endocrinol., 2013, $217(3)$ :R25-R45.

16. PITTELOUD N., MOOTHA V.K., DWYER A.A., HARDIN M., LEE H., ERIKSSON K.L. et al., Relationship Between Testosterone Levels, Insulin Sensitivity, and Mitochondrial Function in Men, Diabetes Care, 2005, 28:1636-1642.

17. CHEN X., LI X., HUANG H.Y., LI X., LIN J.F., Effect of Testosterone on Insulin Receptor Substrate-1 and Glucose Transporter 4 Expression in Cell Sensitive to Insulin, Zhonghua Yi Xue Za Zhi, 2006, 86:1474-1477.

18. CONTRERAS P.H., SERRANO F.G., SALGADO A.M., VIGIL P., Insulin Sensitivity and Testiscular Function in a Cohort of Adult Males Suspected of Being Insulin-Resistant, Front. Med., 2018, 5:190.

19. CHENG J., HAN B., LI Q., XIA F., ZHAI H., WANG N. et al., Testosterone: Relationship with Metabolic Disorders, in MenAn Observational Study from SPECT-China, Int. J. Endocrinol., 2017, Volume 2017, Article ID4547658.

20. LI C., FORD E.S., LI B., GILES W.H., LIU S., Association of Testosterone and Sex Hormone-Binding Globulin with Metabolic Syndrome and Insulin Resistance in Men, Diabetes Care, 2010, 33:1618-24.

21. HANCHANG W., SEMPRASERT N., LIMJINDAPORN T., YENCHITSOMANUS P.T., KOOPTIWUT S., Testosterone Protects Against Glucotoxicity - Induced Apoptosis of Pancreatic $\beta$ Cells (INS-1) and Male Mouse Pancreatic Islets, Endocrinology, 2003, Vol. 154(11):4058-67.

Received January $17^{\text {th }} 2020$ 